\title{
Profile Characteristics of Women Agripreneurs in Kadapa District of Andhra Pradesh, India
}

\author{
C. Lakshmi Devi*, P.L.R.J. Praveen, T. Lakshmi and A.V. Nagavani \\ Department of Agricultural Extension, \\ S.V. Agricultural College, Tirupati-517502, Chittoor District, Andhra Pradesh, India \\ *Corresponding author
}

\section{A B S T R A C T}

\section{Keywords}

Profile

characteristics,

Women

agripreneurs,

Marketing,

Entrepreneurship

Article Info

Accepted:

10 June 2019

Available Online:

10 July 2019

\begin{abstract}
The present investigation was done to study the profile characteristics of women agripreneurs in Kadapa district of Andhra Pradesh. Ex-post facto research design was followed for the study and a sample of 120 respondents was drawn. The results of the study revealed that most of the respondents were middle aged $(62.50 \%)$, educated up to high school (34.16\%). Majority of the women agripreneurs belonged to medium categories with respect to variables of entrepreneurial experience $(72.50 \%)$, social participation $(55.00 \%)$, risk orientation $(70.00 \%)$, innovativeness $(59.17 \%)$, management orientation (60.83\%), decision making ability (71.67\%), medium annual family income (70.00\%), economic orientation $(71.67 \%)$, credit orientation $(44.16 \%)$, extension contact $(59.17 \%)$, mass media exposure $(57.50 \%)$, and training received (65.83\%). The enterprises run by majority $(26.67 \%)$ of the agripreneurs were processed millets and preparation of value added products with millets.
\end{abstract}

\section{Introduction}

The emergence of women entrepreneurs and their contribution to the national economy is quite visible in India. The number of women entrepreneurs has grown over a period of time especially in 1990s. The government of India had implemented a number of programmes for empowerment of the women so as to hasten the entrepreneurship development among rural women and help them to enhance their personal capabilities and increase decision making status in the family and society as a whole and also these programmes have been focused on diversification of agriculture and strengthening of its value addition and its linkage with wider economy. The publicly funded organizations like Krishi Vignan Kendras and others like nongovernmental organizations are providing training either for initiation or refreshment of entrepreneurship. These activities include various forms of food processing like value addition of millets, preservation of fruits and vegetables, making pickles, dairy products and bee keeping. Sustainability of the enterprise largely depends on market linkage. Kadapa district of Andhra Pradesh was 
selected purposively because district has highest number of trained women agripreneurs. KVK located at Utkuru of Kadapa district is conducting a number of trainings on value addition for women agripreneurs. Hence, the study was taken up to assess the marketing behaviour of women agripreneurs.

\section{Materials and Methods}

The study was conducted in Kadapa district of Andhra Pradesh during the year 2018-19. Expost facto research design was followed for the study. Three mandals of Kadapa district and two villages from each mandal viz., Thiruvengalapuram and Rajupalem from Badvel mandal, C.K. Dinne and Utukur villages from C.K. Dinne mandal and Bayanapalle and Upparapalle villages from Chennur mandal were selected by using simple random method from which 120 women respondents were selected. Pre-tested interview schedule was used to collect the primary data and statistical techniques like Arithmetic mean, Standard deviation, Frequencies and Percentage were used.

\section{Results and Discussion}

The results of all selected profile characteristics of women agripreneurs were presented in Table 1.

\section{Age}

The results indicated that more than half $(62.50 \%)$ of respondents were middle aged followed by young (30.83\%) and old age (6.67\%) groups. A critical observation of the above findings indicated that among the women respondents, middle and young age women have been actively involving in entrepreneurial activities compared to old age women. This might be because of the enthusiastic nature of the middle as well as young age women and their proactive attitude towards generating additional income to meet the family needs. The old age women though have an urge to provide financial support to the family, age appears to be the major constraint for their active involvement in entrepreneurial activities. These findings are in conformity with the findings of Deepthi ${ }^{2}$ et al., (2018).

\section{Education}

The findings revealed that most of the respondents $(34.16 \%)$ were educated up to high school followed by college education $(20.86 \%)$ and equal numbers of respondents were illiterate or educated up to primary school (15.83\%). Further, a small percentage of respondents were educated up to middle school $(9.16 \%)$ as well as functionally literate $(4.16 \%)$. This trend revealed that education is the basis for acquisition of knowledge and also provides opportunity to access new information, new ideas for exploitation of existing resources as well as generating additional revenue and innovative ways of earning etc. In fact, accessibility to this information is very critical for success of the entrepreneurs. Education gives confidence to take up entrepreneurship and to develop skills in managing the same. This might be the reason for majority of the respondents involved in entrepreneurial activities were educated. The findings are in line with the results of Sharma and Hussain ${ }^{13}$ (2018).

\section{Entrepreneurial experience}

It is apparent from the results that majority $(72.50 \%)$ of the respondents had medium level of entrepreneurial experience followed by low (15.00\%) and high (12.50\%) levels of entrepreneurial experience. The respondents were from rural background with limited access to education, financial resources and market opportunities. In such situations, it is 
rather difficult to be forthcoming towards taking up entrepreneurial activities. This might be the reason for lack of proactive involvement and delayed decisions in establishing the enterprises. This has naturally reflected the medium and low entrepreneurial experience from the feedback of respondents. These findings are in accordance with the findings of Maratha and Badodiya ${ }^{9}$ (2017).

\section{Social participation}

It is reported that majority $(55.00 \%)$ of the respondents had medium followed by low $(31.66 \%)$ and high (13.34\%) levels of social participation. The possible reason might be that about 50 per cent of the women agripreneurs had membership in social organizations. The low level of involvement could be attributed to the lack of awareness on the benefits to be accrued from enrolment as member of different social organizations. Moreover, the general tendency of the rural entrepreneurs is to spend as much time as possible in their entrepreneurial activities. This has resulted in majority of the respondents falling in medium and a low category as relevant in respect of social participation is little understood. Hence, the women agripreneurs should be appraised of the benefits from participation in social activities and be motivated to enrol as members in different social organizations. This would facilitate them to access more information concerning to the establishment and efficient management of the concerned enterprise and regular update on marketing related issues. The findings are in line with the results of Fayaz ${ }^{5}$ (2015).

\section{Risk orientation}

The findings indicated that 70.00 per cent of the respondents had medium level of risk handling ability followed by high (15.83\%) and low (14.17\%) levels of risk orientation. The probable reason may be the rural women folk don't prefer to take risk especially in financial matters. In addition to this, inherent attitude and price fluctuations in market might have restrained the women agri-preneurs from taking risk. This might be the reason for high percentage of respondents falling under medium category. However, respondents with proven experience in managing the enterprises were willing to take risk for expanding their enterprises anticipating better returns. The result is similar to the findings of Naidu $^{11}$ (2012) and Deepthi ${ }^{2}$ et al., (2018).

\section{Innovativeness}

It is evident from the findings of the study that most $(59.17 \%)$ of the respondents had medium level of innovativeness followed by low $(20.83 \%)$ and high $(20.00 \%)$ levels of innovativeness. This trend revealed that women agri-preneurs used to shoulder dual responsibilities. Besides managing their respective enterprises, they have to attend to family responsibilities. Due to these dual roles, most of the agripreneurs were unable to spare time to think about the innovative changes/improvements. As a consequence, they are not in a position to explore the new opportunities for getting necessary exposure to new ideas and also skill building programmes. Such type of exposure is very important and an essential a prerequisite for idea generation and innovativeness. This might be the reason for majority of the agripreneurs falling in medium category. Similar findings were reported by Madhushekar ${ }^{8}$ (2008) and Verma ${ }^{16}$ et al., (2013).

\section{Management orientation}

It is revealed from the data that majority $(60.83 \%)$ of the respondents had medium level of management orientation followed by high $(24.17 \%)$ and low $(15.00 \%)$ levels of management orientation respectively. The possible reason might be that most of the 
women agripreneurs established the enterprises after undergoing the training through local institutes like KVK or DRDA. Actually, they got the motivation from these centres and also from other successful entrepreneurs who have already started the activity. Even though they got required opportunity to be trained in resource centres, the exposure was adequate enough to get some practical tips but they couldn't gain much knowledge on planning, production and marketing aspects. This might be the reason for most of the respondents falling in medium level of management orientation. The finding is in accordance with those of Vidhyadhari ${ }^{17}$ (2007).

\section{Decision making ability}

It is apparent from the findings of the study that majority $(71.67 \%)$ of the respondents had medium followed by high $(18.33 \%)$ and low $(10.00 \%)$ levels of decision making ability. It could be observed that women agripreneurs though handling the entrepreneurial activities, they generally are not forthcoming to take decisions individually and depend on the family members or other friends. Most of the agripreneurs in study area are from rural household. Although they are more concerned and confident of taking decisions on family issues, they are not capable of taking individual decisions in respect of entrepreneurial activities anticipating risk and failures. On the other hand, the respondents who were well educated could take timely decisions as they were knowledgeable and had good access to information. This might be the reason that high percentage of respondents had medium level of decision making ability. The results are in conformity with those of Naidu $^{11}$ (2012) and Mubeena ${ }^{10}$ (2017).

\section{Annual family income}

It is vivid that majority $(70.00 \%)$ of the respondents had medium followed by high
$(18.33 \%)$ and low (11.67\%) levels of income respectively. The possible reason for this might be that enterprises selected by the respondents in study area were mainly micro enterprises. The respondents were not financially sound and the income from these enterprises could supplement the income earned by men folk from farm and was sufficient only to lead a comfortable life. There was no scope for many of the women agripreneurs to expand the units and improve the economic returns due to financial constraints for additional investments. This might be the probable reason for majority of them falling under medium income group. The findings were in concurrence with those reported by Fayaz ${ }^{5}$ (2015).

\section{Type of enterprise}

It is concluded from the data that 26.67 per cent of the women agripreneurs were handling millets processing units along with preparation of value added products with millets followed by preparation of dairy products $(22.50 \%)$, preparation of juices and jams (20.83\%), pickles (16.67\%), flour mill $(8.33 \%)$, while a few $(5.00 \%)$ were running herbal units.

Millets and horticultural crops occupy major area in Kadapa district. The KVK scientists and DRDA have been conducting training programmes on value addition of minor millets and horticultural crops. Due to abundant availability of the raw material, majority of the women agripreneurs might have shown interest in establishing processing units, value addition with millets and preparation of juices and jams with fruit crops. Dairying is also subsidiary occupation for most of the rural households along with agriculture. Hence, preparation of dairy products was also preferred as an entrepreneurial activity by most of the women entrepreneurs. 


\section{Economic orientation}

It was found that majority $(71.67 \%)$ of the respondents had medium level of economic orientation followed by high $(15.83 \%)$ and low $(12.50 \%)$ economic orientation. The possible reason for this might be that majority of the women agripreneurs were committed towards their entrepreneurial activity and very enthusiastic to achieve the targeted goals and also try new products to earn more money. But finance was a major constraint for majority of the respondents. However, financially sound agriprenuers who gained sufficient experience could go for installation of improved machinery and improved their returns. Thus, the respondents represent diversity in terms of economic orientation and generally have medium level of economic orientation and awareness. The result is in conformity with the findings of Khinmar (2005) and Roy ${ }^{12}$ (2005).

\section{Credit orientation}

The data indicated that most $(44.16 \%)$ of the respondents had medium level of credit orientation followed by low $(34.17 \%)$ and high $(21.67 \%)$ levels. The possible reason for this may be that respondents in study area were not financially sound and were running only micro enterprises. Most of the women agriprenuers had to depend on either institutional or non institutional credit for capital formation and investment in order to establish their enterprises. For getting institutional credit, the respondents had to follow several norms and procedures. Hence, many of them approached non institutional sources for credit. Moreover, most of them were unaware of the financial assistance through government schemes and could not avail the benefits. As a result, most of the respondents fell in medium category with respect to credit orientation. The result is in conformity with the findings of Dillikumar ${ }^{4}$ (2006).

\section{Extension contact}

It is concluded that majority $(59.17 \%)$ of the respondents had medium followed by high $(25.83 \%)$ and low (15.00\%) levels of extension contact. The possible reason may be that respondents in the course of executing the entrepreneurial activities had to contact DRDA officials, bank managers, KVK scientists, fellow entrepreneurs and marketing officials for seeking information, for registration, renewal of license and finance which resulted in majority of the respondents having medium to high level of extension contact. However, there exists a great scope to get updated on the new schemes launched by the State as well as Central Government. The finding is in conformity with the findings of Venkatesan and Vijayalakshmi ${ }^{15}$ (2015) and Grandhi ${ }^{6}$ (2016).

\section{Mass media exposure}

It is apparent that majority $(57.50 \%)$ of respondents had medium followed by high $(25.83 \%)$ and low (16.67\%) levels of mass media exposure respectively. This trend might be due to the fact that to run an enterprise successfully, one needs to gather information from various sources, analyse and utilize it for development of the enterprise. In the study area, the agripreneurs were educated, either middle or young age and they were enthusiastic to gather information from various sources with a view to develop the enterprises and run them successfully. In this context, mass media is one of the easily accessible and popular mode. This might be the reason for majority having medium to high mass media exposure. The results are in line with the findings of Begum ${ }^{1}$ (2008) and Sreeram $^{14}$ (2013). 
Table.1 Distribution of respondents according to their profile characteristics $(n=120)$

\begin{tabular}{|c|c|c|c|c|}
\hline \multirow[t]{2}{*}{ S.No } & \multirow[t]{2}{*}{ Variables } & \multirow[t]{2}{*}{ Category } & \multicolumn{2}{|c|}{ Respondents } \\
\hline & & & Frequency & Percentage \\
\hline \multirow[t]{3}{*}{1} & \multirow[t]{3}{*}{ Age } & Young age & 37 & 30.83 \\
\hline & & Middle age & 75 & 62.50 \\
\hline & & Old age & 8 & 6.67 \\
\hline \multirow[t]{6}{*}{2} & \multirow[t]{6}{*}{ Education } & Illiterate & 19 & 15.83 \\
\hline & & Functionally literate & 5 & 4.16 \\
\hline & & Primary school & 19 & 15.83 \\
\hline & & Middle school & 11 & 9.16 \\
\hline & & High school & 41 & 34.16 \\
\hline & & Collegiate education & 25 & 20.86 \\
\hline \multirow[t]{3}{*}{3} & \multirow{3}{*}{$\begin{array}{c}\text { Entrepreneurial experience } \\
\text { Mean=9.93 } \\
\text { Standard deviation }=6.36\end{array}$} & Low & 18 & 15.00 \\
\hline & & Medium & 87 & 72.50 \\
\hline & & High & 15 & 12.50 \\
\hline \multirow[t]{3}{*}{4} & \multirow{3}{*}{$\begin{array}{c}\text { Social participation } \\
\text { Mean }=1.85 \\
\text { Standard deviation }=0.72\end{array}$} & Low & 38 & 31.66 \\
\hline & & Medium & 66 & 55.00 \\
\hline & & High & 16 & 13.34 \\
\hline \multirow[t]{3}{*}{5} & \multirow{3}{*}{$\begin{array}{c}\text { Risk orientation } \\
\text { Mean }=17.10 \\
\text { Standard deviation }=3.22\end{array}$} & Low & 17 & 14.17 \\
\hline & & Medium & 84 & 70.00 \\
\hline & & High & 19 & 15.83 \\
\hline \multirow{3}{*}{6} & \multirow{3}{*}{$\begin{array}{c}\text { Innovativeness } \\
\text { Mean }=30.66 \\
\text { Standard deviation }=4.26\end{array}$} & Low & 25 & 20.83 \\
\hline & & Medium & 71 & 59.17 \\
\hline & & High & 24 & 20.00 \\
\hline \multirow[t]{3}{*}{7} & \multirow{3}{*}{$\begin{array}{l}\text { Management orientation } \\
\quad \text { Mean }=68.27 \\
\text { Standard deviation }=3.10\end{array}$} & Low & 18 & 15.00 \\
\hline & & Medium & 73 & 60.83 \\
\hline & & High & 29 & 24.17 \\
\hline \multirow[t]{3}{*}{8} & \multirow{3}{*}{$\begin{array}{l}\text { Decision making ability } \\
\quad \text { Mean }=13.49 \\
\text { Standard deviation }=1.82\end{array}$} & Low & 12 & 10.00 \\
\hline & & Medium & 86 & 71.67 \\
\hline & & High & 22 & 18.33 \\
\hline \multirow[t]{3}{*}{9} & \multirow{3}{*}{$\begin{array}{c}\text { Annual family income } \\
\text { Mean }=173.7 \\
\text { Standard deviation }=112.07\end{array}$} & Low & 14 & 11.67 \\
\hline & & Medium & 84 & 70.00 \\
\hline & & High & 22 & 18.33 \\
\hline \multirow[t]{4}{*}{10} & \multirow[t]{4}{*}{ Type of enterprise } & $\begin{array}{l}\text { Processed millets and } \\
\text { value added products }\end{array}$ & 32 & 26.67 \\
\hline & & Flour mill & 10 & 8.33 \\
\hline & & Dairy products & 27 & 22.50 \\
\hline & & Pickles & 20 & 16.67 \\
\hline
\end{tabular}




\begin{tabular}{|c|c|c|c|c|}
\hline & & Juices and Jams & 25 & 20.83 \\
\hline & & Herbal based products & 6 & 5.00 \\
\hline \multirow[t]{3}{*}{11} & \multirow{3}{*}{$\begin{array}{c}\text { Economic orientation } \\
\text { Mean }=21.04 \\
\text { Standard deviation=3.12 }\end{array}$} & Low & 15 & 12.50 \\
\hline & & Medium & 86 & 71.67 \\
\hline & & High & 19 & 15.83 \\
\hline \multirow[t]{3}{*}{12} & \multirow{3}{*}{$\begin{array}{c}\text { Credit orientation } \\
\text { Mean }=2.27 \\
\text { Standard deviation }=1.26\end{array}$} & Low & 41 & 34.17 \\
\hline & & Medium & 53 & 44.16 \\
\hline & & High & 26 & 21.67 \\
\hline \multirow[t]{3}{*}{13} & \multirow{3}{*}{$\begin{array}{c}\text { Extension contact } \\
\text { Mean }=5.46 \\
\text { Standard deviation }=2.33\end{array}$} & Low & 18 & 15.00 \\
\hline & & Medium & 71 & 59.17 \\
\hline & & High & 31 & 25.83 \\
\hline \multirow[t]{3}{*}{14} & \multirow{3}{*}{$\begin{array}{c}\text { Mass media exposure } \\
\text { Mean }=8.75 \\
\text { Standard deviation }=2.97\end{array}$} & Low & 20 & 16.67 \\
\hline & & Medium & 69 & 57.50 \\
\hline & & High & 31 & 25.83 \\
\hline \multirow[t]{3}{*}{15} & \multirow{3}{*}{$\begin{array}{c}\text { Training received } \\
\text { Mean }=0.65 \\
\text { Standard deviation }=0.47\end{array}$} & Low & 41 & 34.17 \\
\hline & & Medium & 79 & 65.83 \\
\hline & & High & 0 & 0.00 \\
\hline \multirow[t]{3}{*}{16} & \multirow{3}{*}{$\begin{array}{c}\text { Market facilities } \\
\text { Mean }=26.42 \\
\text { Standard deviation }=4.03\end{array}$} & Low & 18 & 15.00 \\
\hline & & Medium & 83 & 69.17 \\
\hline & & High & 19 & 15.83 \\
\hline \multirow[t]{3}{*}{17} & \multirow{3}{*}{$\begin{array}{c}\text { Market intelligence } \\
\text { Mean=9.09 } \\
\text { Standard deviation=2.40 }\end{array}$} & Low & 31 & 25.83 \\
\hline & & Medium & 76 & 63.33 \\
\hline & & High & 13 & 10.84 \\
\hline
\end{tabular}

\section{Training received}

From the data it could be inferred that the respondents received either medium level of training $(65.83 \%)$ or low level of training $(34.17 \%)$. The possible reason might be that women agripreneurs are being trained either by DRDA or KVK before establishing the enterprise. But after establishing the enterprise, the respondents rarely attended the trainings for skill enhancement as they were pre-occupied with running and managing the enterprise. Moreover, they were less interested to participate in training by sacrificing their working hours. The same trend was reflected in the data generated. The findings are in accordance with those reported by Naidu ${ }^{11}$ (2012).

\section{Market facilities}

It is clear from the data that the majority $(69.17 \%)$ of respondents had medium market facilities followed by more or less equal per cent of respondents having high $(15.83 \%)$ and low $(15.00 \%)$ market facilities respectively. It could be observed that enterprises selected by the respondents in study area were mainly micro enterprises and confined to rural areas. Thus, the transport facilities as well as 
marketing outlets are generally inadequate. The women entrepreneurs had to rely mainly upon middle men and commission agents for marketing their products. Provision of more number of outlets in nearby town and permitting sales in Rythubazars by the government can help the women entrepreneurs to overcome the problems in marketing. Thus the observed trend among respondents clearly reflected the shortfalls in the availability of market facilitates. The findings are not in conformity with the findings of Sreeram ${ }^{14}$ (2013).

\section{Market intelligence}

It is clear from the data that majority $(63.33 \%)$ of the respondents had capable category of market intelligence followed by less capable $(25.83 \%)$ and $(10.84 \%)$ were found in most capable category of market intelligence. The possible reason for this may be that market intelligence is an essential factor which enables to make appropriate market decisions. In the study area, majority of the women agripreneurs had no proper access to market information and resources which may be because of lack of interest in accessing market information and resources, lack of exposure and lack of social mobility. This might be the possible reason for most of the women agripreneurs falling in capable and less capable category of market intelligence. The findings are not in accordance with the findings of Dhara ${ }^{3}$ (2010).

The findings of the study clearly revealed that majority of the women agripreneurs were middle aged, educated up to high school with medium level of income, experience in enterprise, social participation, innovativeness, risk orientation, decision making ability, mass media exposure, economic orientation, training received, extension contact, management orientation, market facilities and capable level of market
intelligence.The findings augment the need for encouraging the women folk to be educated, enroll as members in social institutions and also there is a need for conducting more number of skill oriented training programmes to the women entreprenuers and linking them to financial institutes for getting loans and also empowering them through formation of self help groups.

\section{Acknowledgement}

Thanks to Acharya N.G. Ranga Agricultural University and special thanks to KVK, Utkuru and Department of Agricultural Extension for providing information and infrastructure facilities during my research.

\section{References}

1. Begum MK. A study on participation and decision making of women farmers in rainfed groundnut cultivation. M.Sc.(Ag.) Thesis. Acharya N.G. Ranga Agricultural University, Hyderabad, 2008.

2. Deepthi V, Rambabu P, Gopikrishna T and Vishnu D. Profile characteristics of agripreneurs in Andhra Pradesh. The Andhra Agricultural journal 2018; 65(1): 230- 234.

3. Dhara R. Marketing behaviour of coconut growers and inventorising coconut value added products - a stakeholders analysis. Unpub. M.Sc. (Ag.) Thesis. AC\&RI, TNAU, Madurai, 2010.

4. Dillikumar V. Training Needs of SHG Women Members in Jasmine Cultivation, Unpub. M.Sc. (Ag.) Thesis. Annamalai University, Annamalai Nagar, 2006.

5. Fayaz S. Entrepreneurial Behaviour of Cotton farmers in Kurnool district of Andhra Pradesh. M.Sc. (Ag.) Thesis. Acharya N.G. Ranga Agricultural 
University, Hyderabad, 2015.

6. Grandhi. A critical study on women empowerment through self help groups (SHGs). M.Sc. (H.Sc.) Thesis. Professor Jayashankar Telangana State Agricultural University Rajendranagar, Hyderabad, 2016.

7. Khinmar O. Knowledge and adoption of improved dairy management practices by women dairy farmers in Dharward district. M.Sc. (Ag.) Thesis. University of Agricultural Sciences, Dharward, 2005.

8. Madhushekhar BR. A study on marketing behaviour of chilli growers in Guntur district of Andhra Pradesh. M.Sc. (Ag.) Thesis. Acharya N. G. Ranga Agricultural University, Hyderabad, 2008.

9. Maratha $\mathrm{P}$ and Badodiya SK. Study on marketing behaviour and other attributes of vegetable growers at Kota block of Kota district in Rajasthan. International journal of pure and applied bioscience 2017; 5 (1): 329337.

10. Mubeena. A study on entrepreneurial behaviour of rural women of Podupu Laxmi Ikya Sangam in Kurnool district of Andhra Pradesh. M.Sc. (Ag.) Thesis. Acharya N G Ranga Agricultural university, Guntur, 2017.

11. Naidu CD. Study on farming performance and entrepreneurial behaviour of sugarcane farmers in north coastal zone of Andhra Pradesh. Ph.D. Thesis. Acharya N.G. Ranga Agricultural University, Hyderabad, 2012.

12. Roy S. A study on the sustainability of sugarcane cultivation in Vishakhapatnam district of Andhra Pradesh. Ph.D. Thesis. Acharya N. G. Ranga Agricultural University, Hyderabad, 2005.

13. Sharma A and Hussain M. Identification of constraints for tiny women farmers in the district of Nainital. Indian journal of social research 2018; 59(6):859-865.

14. Sreeram. A study on entrepreneurial behaviour of members of kudumbasree NHGs in Palakkad district of Kerala. M.Sc. (Ag.) Thesis. Acharya N. G. Ranga Agricultural University, Hyderabad, 2013.

15. Venkatesan $P$ and Vijayalakshmi $P$. Training needs of farm women towards entrepreneurial development, Journal of Extension Education 2015; 27 (1).

16. Verma NK, Pandey DK and Upadhayay AD. Performance evaluation of fishery based self help groups in West Tripura. Indian Research Journal of Extension Education 2013; 13(3): 15-18.

17. Vidhyadhari B. Entrepreneurial behaviour of prawn growers in Nellore district of Andhra Pradesh. M.Sc. (Ag.) Thesis. Acharya N.G. Ranga Agricultural University, Hyderabad, 2007.

\section{How to cite this article:}

Lakshmi Devi, C., P.L.R.J. Praveen, T. Lakshmi and Nagavani, A.V. 2019. Profile Characteristics of Women Agripreneurs in Kadapa District of Andhra Pradesh, India. Int.J.Curr.Microbiol.App.Sci. 8(07): 924-932. doi: https://doi.org/10.20546/ijcmas.2019.807.111 